\title{
Political Economy or Political Systems? How Welfare Capitalism and Political Systems Affect Law and Order Policies in Twenty Western Industrialised Nations
}

\author{
Georg Wenzelburger \\ Department of Social Sciences, TU Kaiserslautern, Germany \\ E-mail: georg.wenzelburger@sowi.uni-kl.de
}

There has been little comparative policy research hitherto on the substantial differences in law and order policies between Western industrialised countries. Instead, criminologists have filled this void and used concepts such as Esping-Andersen's worlds of welfare or Lijphart's patterns of democracy to interpret cross-country variation. However, the state of the art has two weaknesses: it almost exclusively relies on imprisonment data as dependent variable and it remains silent as to why welfare state regimes or types of democracy should be responsible for similarities in law and order policies. The present article tackles these shortcomings by (1) examining differences and commonalities in law and order policies in twenty Western industrialised countries and by (2) investigating whether the clustering of countries is associated with features of the welfare state or the political system. We find three distinct clusters and show that their formation is related to the characteristics of the political economy of the countries.

Keywords: Consensus democracy, law and order, political economy, welfare state regimes.

\section{Introduction}

In recent years, comparative criminologists have increasingly used concepts from political science to make sense of the variations in law and order policies throughout Western industrialised countries. Two main arguments have been put forward. ${ }^{1}$ First are those studies that emphasise the important influence of the capitalist political economy in general (Lacey, 2008) and the welfare state in particular (Sutton, 2004; Cavadino and Dignan, 2006, 2014; Downes and Hansen, 2006). Cavadino and Dignan (2006, 2014), for instance, compare imprisonment rates and indicators of penal severity, and find that the penal policies of Western industrialised countries follow the well-known welfare state regimes identified by Esping-Andersen (1990). Second are those studies that emphasise instead the differences in the architecture of political systems and suggest that such differences can explain why Western industrialised countries differ in terms of their law and order policies. Lappi-Seppälä (2008), for instance, finds that the type of democracy as developed by Lijphart $(1999,2012)$ is closely linked to different indicators of law and order and penal severity. The reasons are mainly to be found in the political culture that consensus and majoritarian democracies promote (Pratt, 2008; Savelsberg, 2011) and the party competition linked to different electoral systems (Newburn, 2007).

Although these studies have to be applauded for pointing out that political and economic characteristics seem to matter for law and order policies, several shortcomings 
persist in this literature. First, on an empirical level, existing studies often only use one specific indicator, most commonly imprisonment rates, to examine how countries differ with respect to this variable. This is a pity given that concepts like law and order, or punitivity, are multidimensional and can hardly be assessed using only one measure (Matthews, 2005; Frost, 2008; Kury and Ferdinand, 2011). Second, on a theoretical level, the relationships between regime typologies and the variations in law and order policies have not been established in a convincing way. Most studies restrict themselves to finding empirical patterns without answering the question as to why law and order policies should resemble a certain typology. And if some studies discuss possible explanations for the observable country differences, it is rather unclear how these are related to each other, to the overall regime concept used and to the outcome. Hence, the mechanisms that supposedly create the country clusters are rather vague. ${ }^{2}$

These two shortcomings of the existing literature are the starting point of the present article. We address the existing limitations of the state of the art by investigating: (1) how Western industrialised countries cluster in terms of their law and order policies and (2) whether the country clusters differ in a way that can be associated with comparative political science frameworks. In answering these questions, the present article contributes to the existing literature in three ways. First, by bringing together insights from criminology and political science, we present a theoretical discussion of the relationships that could explain why features of either the political economy or the political system may be related to law and order policies. Second, we use six different variables linked to law and order policies in a broadly defined way, and hierarchical cluster analysis to investigate whether countries cluster in distinct groups. Hence, we move beyond the analysis of imprisonment rates, which has been the standard approach in criminology for years, and use a broader concept of law and order (more on this in the section on research design, operationalisation, data and methods) (for a similar endeavour, see Karstedt, 2015). We indeed find three different country clusters that resemble more the worlds of welfare capitalism and less the types of democracy. Third, we investigate by means of a linear discriminant analysis in what way the country clusters differ from each other. We find that labour market regulation and the structure of the capitalist system, as well as the professionalisation of the bureaucracy, seem to matter much more than variables linked to the political system or cultural factors.

The remainder of this article is structured as follows: the theoretical relationships are discussed in the next section, followed by a section that presents the data, variables and methods. The empirical analysis is to be found in the subsequent section, while the final section discusses the results and concludes.

\section{Theory: why should countries cluster?}

The literature dealing with differences and commonalities of law and order policies in Western industrialised countries is mainly criminological and rather young. One of the fathers of the recent literature was, maybe unintentionally, David Garland who suggested that a uniform trend towards harsher policies would occur in the US 'and elsewhere' (Garland, 1996: 442) - hence in the entire Western world (similarly Pratt, 2007: 94). In reaction to this 'elsewhere'-hypothesis, more and more studies discovered marked differences between the nation states (Cavadino and Dignan, 2006; Tonry, 2007a), especially in Europe (Snacken, 2010; Snacken and Durmontier, 2012). Thus, the main 
impetus of the entire strand of the literature was clearly empirical in nature: The aim was to demonstrate real-world variation between countries and to refute the thesis of a general trend towards ever-harsher law and order policies:

As icy trade winds of punitive law and order ideology seemingly sweep the globe, we need to hold fast to the recognition that things can be done differently to the dictates of the current gurus of penal fashion. (Cavadino and Dignan, 2006: 4)

This largely empirical starting point also explains that theoretical accounts of why there should be differences between countries have only been developed at the margin. The existing studies mostly discuss explanatory factors 'ad hoc'. Again, the influential book of Cavadino and Dignan is a case in point. Although the authors identify different 'worlds' of penal systems and refer to the concept of Esping-Andersen, they remain suspiciously silent on the question why these different worlds should have formed and what EspingAndersen's power resources explanation of the three worlds of welfare capitalism has to do with it. In order to address this theoretical shortcoming, this section will first discuss how major accounts in the criminological literature explain differences in law and order policies. In a second step, we will then ask whether these explanations can be related to the concepts used by comparative criminologists in order to make sense of the crosscountry variation - namely Lijphart's differentiation between consensus and majoritarian democracies and Esping-Andersen's typology of different worlds of welfare capitalism.

\section{Criminological explanations}

The criminological literature on explanations for law and order policies is rather unsystematic - but there are at least six different approaches that can be distilled from the literature. The crime link is the most obvious explanation for law and order policies as it suggests a functional relationship between the crime rate and law and order policies. The state is said to respond to higher crime rates (Bottoms, 1995; Gottfredson and Hindelang, 1979) or the perception of a higher crime rate by the middle class (Garland, 2001) by means of tougher law and order policies and increased punishment.

The labour surplus link dates back to the work by Rusche and Kirchheimer (1968) and has been further development since (Jankovic, 1977; Greenberg, 1983; Chiricos and Delone, 1992). It proposes a direct relationship between the labour market (essentially: unemployment) and the use (and the severity) of penal policies - unrelated to the development of actual crime. Different reasons are held responsible for this (see: Chiricos and Delone, 1992), the most prominent being deterrence: 'Punishment is expected to be more severe during economic crises because the policy of deterrence dictates an intensification of punishment in order to combat the assumed increased temptation to commit crime' (Jankovic, 1977: 20). Over time, several siblings of the original approach have been created - arguing that not only unemployment, but also poverty or inequality are responsible for increased imprisonment which is, again, used to deter the poor from committing crimes (Wacquant, 2009).

The insecurity link suggests that feelings of insecurity among citizens have increased during the last decades because of very different developments such as the emergence of postmodernism and the risk society characterised by profound value change, omnipresence of risk in everyday life, insecurity of labour markets and so forth (Beck, 
1986, 2011; Giddens, 1990; Beck et al., 1994; Bauman, 1999). Building on the insight that a substantial transformation of Western societies is occurring, criminologists argue that governments try to counter these very general feelings of insecurity by demonstrating security via law and order policies (Singelnstein and Stolle, 2012; Mythen, 2014).

The political culture link considers law and order policies to be a consequence of different political cultures: 'Demand for punishment seems to be highest in societies that have a strong commitment to individualistic means of social achievement' (Sutton, 2004: 171). According to this approach, the cultures of nation-states and societies differ in terms of some basic values such as solidarity, trust or competition and individual achievement a difference which is rooted in the historical heritage of these countries (Savelsberg, 2000). Scandinavian countries and their penal 'mildness' has often be explained by their 'culture of equality' (Pratt, 2008) or the importance of values like solidarity and social trust (Lappi-Seppälä 2014: 313). A similar argument has been made for the variations between American states (Newburn, 2006: 257), building on Elazar's distinction between three types of 'political culture' in the US (Elazar, 1966).

The party competition link regards law and order policies as dependent on the dynamics of party competition and electoral systems (Jacobs and Helms, 2001; Newburn, 2007; Lacey, 2010, 2011). First-past-the-post electoral systems, which foster fierce partisan competition of two parties (or party blocks), have been found to create a spiral where the two parties compete intensely on law and order issues and move their ideology and their policies gradually in a more repressive direction - a dynamic Lacey has termed 'prisoner's dilemma' (Lacey, 2008). A political actor who tries to pursue harsher policies in order to win votes will therefore have a much greater incentive to do so in two-party systems.

Finally, several studies emphasise the impact of professional bureaucracy, i.e. expert civil servants on law and order policies (Savelsberg, 1994; Tonry, 2007b: 312) (bureaucracy link). Countries with a tradition of expert and non-political civil servants are said to exhibit less repressive law and order policies (Garland, 2001: 150) because an apolitical bureaucracy may shield the policy-making process from populist tendencies in a law and order context. Savelsberg forcefully argues that one has to account for these different 'nation-specific institutional structures of knowledge-production' (Savelsberg, 1994: 939) when explaining differences in law and order policies.

\section{Linking political science and criminology}

The criminological explanations summarised above can be related to the broad concepts from political science, which focus on the characteristics of political systems or on features of the political economy in order to explain variation in law and order policies. Lijphart's distinction between consensus and majoritarian democracies (Lijphart, 2012) has been introduced into the debate by Lappi-Seppälä (2008: 367) who argues that:

[c]onsensus brings stability and deliberation. Political changes are gradual, not total as in majoritarian systems in which the whole crew changes at one time. In consensus democracies, new governments rarely need to raise their profiles by making spectacular policy changes. Consensus criminal justice policy places value in long-term consistency and incremental change .... In short, consensus politics lessen controversies, produce less crisis talk, inhibit dramatic turnovers, and sustain long-term consistent policies. Consensus democracies are less susceptible to political populism. (Lappi-Seppälä, 2008: 377) 
From the quote, it is obvious that two of the six criminological linkages are rather directly referred to. First, the party competition link is addressed using the argument that majoritarian electoral systems, which produce single party governments and 'spectacular policy changes' every time the government changes, are more susceptible to political populism in the realm of law and order. This is very much in line with the argument put forward by Lacey (2008, 2010: 62-77) or Newburn (2007) according to which a PR system that creates coalition cabinets and which leads to less intense party competition will successfully dampen self-reinforcing competition regarding ever harsher law and order policies. In contrast, in first past the post systems, which tend to bring about two major parties, fierce partisan competition between the two competitors generates a race to the top in terms of law and order harshness because the two parties outpace each other with a 'tough on crime' electoral strategy to win votes. ${ }^{3}$ Second, Lappi-Seppälä also argues that consensus democracies foster a certain political climate characterised by consensus and a culture of trust (Lappi-Seppälä, 2008: 379). This argument resembles the political culture link, which links cultural values such as solidarity to law and order policies and has been used particularly to explain why law and order policies are substantially less repressive in Scandinavian countries (Pratt, 2008)

The second strand of the comparative work on differences in law and order policies emphasises the importance of the political economy. Again, several interconnections between the two most important political science concepts of the political economy the welfare-capitalism-approach (Esping-Andersen, 1990) and the varieties of capitalism framework (Hall and Soskice, 2001) - and the criminological explanations can be pinned down.

First, the organisation of the welfare state directly affects the labour surplus link. The more de-commodifying the welfare state, the less the degree of inequality and poverty is to be expected. In addition, the commitment to full employment in Scandinavian welfare states should also impede governments from using deterrence strategies such as harsher punishment as proposed by the labour-surplus link. Similarly, the varieties of capitalism approach also points to differences in labour-market regulations between capitalist systems, with coordinated market economies (CMEs) aiming to integrate a maximum number of people into the labour markets by investing in public education, re-training programs, etc. Instead, in liberal market economies (LMEs), prisons have 'become a mechanism for "warehousing" those excluded from the legitimate economy' (Lacey, 2012: 14). Second, the welfare state also affects the insecurity link - via de-commodification and stratification. A more generous welfare state should make people feel less insecure because it reduces different risks linked to poverty and loss of income (health, disability, unemployment). Moreover, a conservative-corporatist welfare state, which guarantees the maintenance of status due to class- and status-based social rights (stratification), should also decrease feelings of insecurity. The same is true in CMEs. In sum, for both reasons, the state should have much less reason to resort to harsher law and order policies aimed at creating a feeling of security in more generous welfare states. Finally, as a third mechanism, Lacey argues that the impact of professional bureaucrats on policies varies according to the type of capitalism (Lacey, 2008: 72-7): In LMEs, the impact of professional bureaucrats on public policies is lower with the result that 'once a professional bureaucracy is undermined, one of the main tools for depoliticising criminal justice is removed' (Lacey, 2008: 74). In CMEs, in contrast, civil servants have remained in a strong position. These experts are isolated from the political game, which enables them to resist tendencies 
Table 1 Criminological explanations and political science regime approaches

\begin{tabular}{|c|c|c|}
\hline Crime link & Political economy & Political systems \\
\hline Labour surplus link & $\begin{array}{l}\text { Unemployment protection } \\
\text { Inequality Poverty }\end{array}$ & \\
\hline Insecurity link & $\begin{array}{l}\text { De-commodification } \\
\text { Stratification } \\
\text { Regulation of labour markets }\end{array}$ & \\
\hline Political culture link & & $\begin{array}{l}\text { Consensus culture, trust, } \\
\text { solidarity }\end{array}$ \\
\hline Party competition link & & $\begin{array}{l}\text { Electoral system } \\
\text { Party system }\end{array}$ \\
\hline Bureaucracy link & Professional bureaucracy & \\
\hline
\end{tabular}

towards penal populism. Indeed, this strength of professional bureaucracy may relate to overall patterns of strategic coordination present in coordinated political economies, even outside the economic sector. At any rate, this relationship between the structure of the political economy and the strength of a professional bureaucracy relates directly to the bureaucracy link in the criminological literature.

Interestingly, the six criminological explanations of law and order policies are systematically related to the two main explanatory concepts from political science political economy and political systems (see Table 1). Whereas the welfare state and the structure of the capitalist economy can be linked to law and order policies via the labour market - the feelings of insecurity and the strength of professional bureaucracy differences in the institutional structure of political systems (e.g. distinguishing between majoritarian and consensus democracies) are said to affect law and order policies via the party competition they generate and the political culture that is present in such systems. Clearly, resemblances between political systems and welfare state regimes exist (Lacey, 2008). Cusack et al. (2007) has shown for instance that, historically, the electoral system has affected the development of a certain type of capitalism. Thus, the impact of electoral systems could, in principle, not only work via party competition (political systems) but also via the welfare state. However, since the formation of a certain form of welfare capitalism much time has passed. Countries' welfare states as well as capitalist regimes have changed tremendously in recent decades (Schneider and Paunescu, 2012; SeeleibKaiser, 2016) and not always in line (or in opposite directions) with the much less dynamic electoral systems. Hence, while not denying resemblances at the start, it seems reasonable to disentangle the two explanatory concepts and the respective links to law and order policies when analysing law and order policies in the beginning of the 2000s.

From this discussion, it is possible to derive hypotheses that can be used to test empirically which of the explanatory concepts - political economy or political systems is better equipped to explain cross-country variations in law and order policies. Discussing political economy first, we expect that:

Hypothesis - political economy 1. Countries with higher unemployment protection, less inequality and poverty have more lenient law and order policies (H-PE-1 - labour surplus link); 
Hypothesis - political economy 2. Countries with a welfare state characterised by a higher degree of de-commodification and stratification as well as a highly regulated labour market have more lenient law and order policies (H-PE-2 - insecurity link);

Hypothesis - political economy 3. Countries with a strong and professional (nonpolitical) bureaucracy have more lenient law and order policies (H-PE-3 bureaucracy link).

In contrast, the arguments in the literature emphasising the relevance of the characteristics of the political system yield the following hypotheses:

Hypothesis - political solidarity 1. Countries with a political culture of solidarity and trust have more lenient law and order policies (H-PS-1 - political culture link);

Hypothesis - political solidarity 2. Countries with a multiparty system and a PR electoral system have more lenient law and order policies (H-PS-2 - party competition link).

\section{Research design, operationalisation, data and methods}

The research design follows the twofold goal of this article. In order to answer the first research question, whether countries cluster according to one of the regime concepts, we will conduct a hierarchical cluster analysis based on several indicators linked to law and order policies. The cluster analysis is mainly exploratory in nature and aims at examining differences and commonalities in law and order policies throughout the Western world. Building on these insights, we will then perform a linear discriminant analysis to assess the second research question, namely which variables are responsible for the groupings of the countries.

The cluster analysis is based on a set of six variables, the choice of which follows conceptual reasons. Following Kury and Ferdinand, we distinguish between a judicial and a legal (and, thus, political,) dimension of law and order (Kury and Ferdinand, 2011). Given the explanatory model, which focuses much more on the political dynamics of law and order policies, we restrict our conceptualisation to the political dimension, i.e. aspects of law and order policies (legislation, spending, etc.). What indicators, then, represent different aspects of such a political dimension of law and order? Undoubtedly, legislative output would be the most direct way to measure the policy stance of a certain country. However, as comparable data on several countries' legislation is not available, case studies are, for the moment, the only way to assess the development of legislation in different countries (for England and Wales: Farrall et al., 2016; for Germany: Wenzelburger and Staff, 2016).

Given this restriction, we therefore follow Lowi (1972) and use six variables that represent the regulative and distributive dimension of law and order policy-making. On the regulative side (e.g. rules governing individual behaviour in penal law), we use three indicators from the 'democracy barometer' (Merkel et al., 2014; Wagner and Kneip, 2015) that capture: (1) the extent to which a country is under the secure rule of law, (2) the degree of inhumane or degrading punishment and (3) the extent to which the freedom of the citizens to exercise and practice their religious beliefs is subject to government restrictions. ${ }^{4}$ The democracy barometer is particularly well suited for capturing the regulatory framework because it sets out to measure the quality of democracy beyond the 
distinction between democratic and non-democratic countries. Therefore, the data reveal considerable variation between Western industrialised countries (Bühlmann et al., 2012). The distributive part is approximated by three indicators that reflect government decisions on resources: (1) the number of police officers in a country, (2) the general government expenditures on public order and safety and, finally, (3) the extent of imprisonment. ${ }^{5}$ Again, although interrelated, these indicators reflect different aspects of the distributive dimension. Take government expenditure as an example: Indeed, spending on law and order is affected by the extent of imprisonment and the number of police officers, but it also reflects investment in surveillance techniques (CCTV), data collection etc. The fact that the highest correlation between the three indicators only amounts to 0.37 also indicates that the variables grasp distinct aspects of the distributive dimension.

As we are mainly interested in cross-country variance at a very aggregate level, we use arithmetic means for the period 1998 to 2010 for all indicators, which leaves us with twenty observations. ${ }^{6}$ Indeed, looking at temporal variance, too, would be interesting in order to discover the causal relationships that lead to tougher or more lenient policies. However, as the main aim of this article is to grasp cross-country variance, and as the theories reviewed before argue that different levels of law and order policies are to be expected in different types of welfare states or political systems, we restrict the analyses to the theoretically most relevant cross-sectional dimension that is to the differences in levels between the countries. ${ }^{7}$ In terms of the cluster algorithm, we use the Ward method (hierarchical clustering) based on the z-standardised values of the indicators. However, other algorithms (e.g. complete or average linkage) yield similar results. Country clusters are identified via visual inspection of the dendrograms.

Linear discriminant analysis (LDA) is used to see how well the explanatory factors identified above discriminate between the country groups ('descriptive discriminant analysis' (Huberty and Olejnik, 2006)). Admittedly, the number of observations is small $(N=20)$, which is why we include only a few independent variables into one model at a time. ${ }^{8}$ Besides, we will not draw general inferences from our data and restrict ourselves to a description of the patterns found in the twenty countries under observation. ${ }^{9}$ This lowkey approach means that some of the assumptions which would be crucial for drawing inferences from a sample to the population do not necessarily need to be met (Berk, 2010). For our purposes, it also makes sense on theoretical grounds because the relationships discussed above only refer to the world of Western industrialised countries.

Each hypothesis derived above is represented by at least one independent variable (see online appendix, Table 1). In addition, we include the homicide rate (see 'crime link' above) and the unemployment rate to account for the two most prominently discussed drivers of law and order policies. As the discriminant analysis is based on the results of the cross-sectional cluster analysis, we use the means of the independent variables between 1998 and 2010. In the rare case of missing data (e.g. the Gini-coefficient), the means were calculated from less than the entire period.

Clearly, our methodology based on pattern-identification via cluster analysis and the assessment of the relationship between the explanatory variables and the cluster result using LDA cannot be interpreted as a genuine test of causal mechanisms. Instead, our method comes down to what Berk (2010) calls a 'descriptive regression', directed at identifying patterns in the data and relationships between explanatory variables and an outcome - in our case law and order policies. 

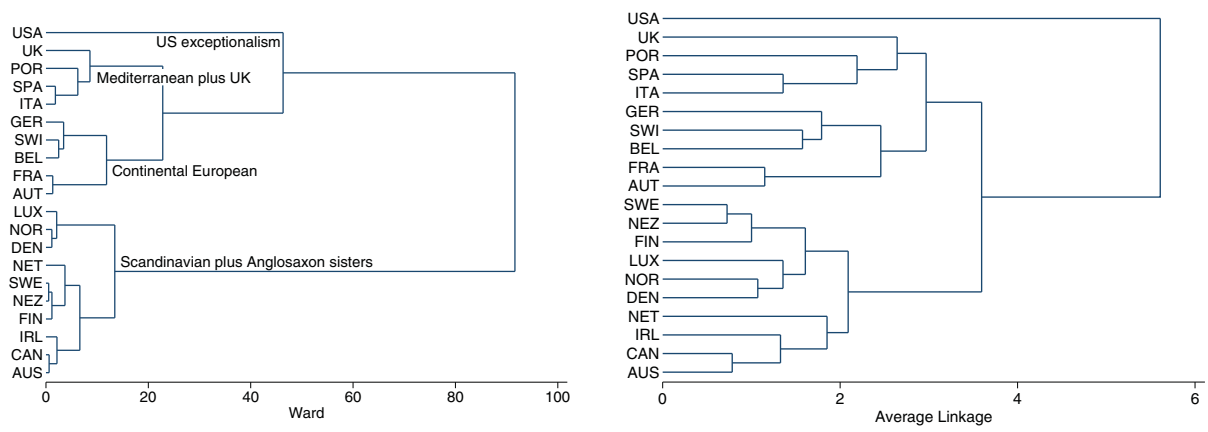

Figure 1. (Colour online) Cluster analysis

Note: Results from a hierarchical cluster analysis (Ward-algorithm (left), average linkage (right)) on the six variables (data, see Online Appendix).

\section{Empirical analysis}

Identifying clusters

The first step of the empirical analysis answers the question on whether we see specific country patterns in terms of law and order policies and whether they resemble one of the typologies discussed above. A first impression of the cross-country variance can be obtained by ranking the countries according to the six underlying variables. The US and Spain, for instance, rank among the top four most repressive countries in four of the six categories, whereas Norway is often among the least repressive (five times among the four least repressive). Besides, Germany seems to fulfil the expectation of having a middleway-profile (Schmidt, 1987, 2001). Finally, looking at the means, standard deviations and eventual outliers, it is obvious that the extremely high imprisonment rate in the US is a particularity well-known from the literature.

However, from this first look at the data, it is not possible to judge whether the countries under review are systematically similar or dissimilar. Therefore, we have run a number of hierarchical cluster analyses using the six variables. Cluster analyses create groups of countries that are as homogenous as possible and as different as possible from each other. As a result of this process, and independent of the cluster algorithm, we obtain a solution with four clusters (see Figure 1). However, the first cluster is not a country group, but a single nation: the United States. ${ }^{10}$ The fact that the US seem to play a completely exceptional role was already observable in the raw data and the analysis corroborates this impression. The second cluster consists of three Mediterranean countries (Portugal, Spain and Italy) and the UK. Depending on the algorithm, the UK joins this cluster sooner or later. The third cluster unites five Continental European countries, namely Germany, Switzerland and Belgium as well as France and Austria. Finally, the remaining forth cluster is larger and more heterogeneous. It includes the Nordic countries (Sweden, Finland, Norway and Denmark), the four remaining Anglo-Saxon countries in our sample (Ireland, Canada, Australia, New Zealand) as well as the Netherlands and Luxemburg.

In order to see in what respects the country groups differ from each other, we have calculated the means of the underlying variables for the three clusters and analysed 


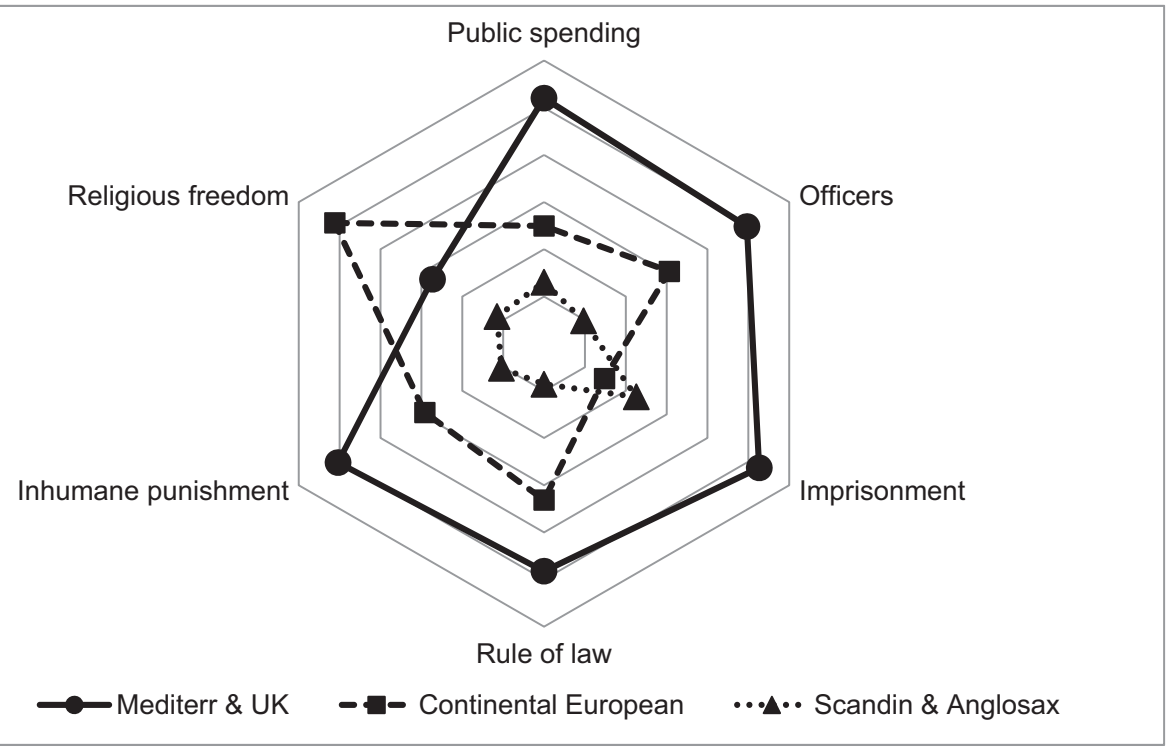

Figure 2. Cluster characteristics

Note: For illustration the data have been z-standardised. Higher values (points distant to the center) indicate a more repressive stance, lower values (points close to the center) a more lenient stance.

the variances (excluding the US). The results show significant differences ${ }^{11}$ between the groups (Figure 2): The Mediterranean cluster (and the UK) is the most repressive on all variables except religious freedom where the countries in the Continental European cluster are more restrictive. At the same time, the Continental European countries have least people incarcerated and rank in a mid-position on all the other four variables. Finally, the Scandinavian and Anglo-Saxon countries (without the UK) are the most liberal in all variables except imprisonment where they are joined by the Continental European countries (and outpaced, but only to a small degree).

How well does this result mesh with the well-known typologies from political science? Clearly, the law and order cluster are more similar to welfare capitalist regimes than to types of democracies (see Online Appendix, Table 2). The Mediterranean cluster and the Continental European cluster are very close to welfare regimes as found by EspingAndersen (1990) or Ferrera (1996). Besides, the Nordic countries and the Netherlands (which are, according to Esping-Andersen's original classification, part of the socialist world - Esping-Andersen 1990: 74), stick together. However, the Liberal world is divided in two groups: one group, the 'Anglo-Saxon sisters', i.e. the former colonies of the UK as well as Ireland join the Nordic countries and the Netherlands and form a heterogeneous group; the other two countries of the liberal world, the US and the UK, follow a clearly different path. The UK joins the Mediterranean countries, and the US constitutes an even tougher world of its own. In contrast, Lijphart's concept of consensus and majoritarian does not resemble the law and order clusters to any great extent. Although the Continental European cluster is dominated by consensus democracies, the other two country groups consist of both, consensus and majoritarian democracies. 


\section{Explaining clusters}

The cluster analysis has shown that the twenty Western industrialised countries under review cluster in three distinct groups with the exception of the United States, which follows its own policy path. However, besides some first guesses, based on interconnections with regime typologies, we do not know whether the country groups are characterised by specificities linked to their political systems or their political economy. It is to this question this section turns. We will report results from the linear discriminant analyses, which relate the hypotheses derived above to the three country clusters. As the number of cases is limited to nineteen, ${ }^{12}$ we have estimated parsimonious models beginning with the two control variables (homicide and unemployment rate), augmenting the models stepwise to a maximum of six independent variables. Table 2 therefore presents four models, including only those variables related to the political economy and representing the three hypotheses from this strand. Models 5 and 6, instead, include variables related to the type of democracy. The two last models $(7,8)$ finally combine influential indicators in order to maximise the eigenvalue and the classification result while dropping less influential indicators. The robustness of the models has been checked by excluding one country at a time and comparing the classification results. If results vary suspiciously, this is reported in a footnote.

The results of the linear discriminant analysis corroborate the impression we already had when interpreting the results of the cluster analysis. The indicators on the political system discriminate rather poorly between the three clusters: neither the party system and the electoral system nor the cultural variable measuring individualism versus collectivism yield a result which separates the three clusters clearly from each other. In contrast, those indicators linked to the political economy yield much better discrimination between the groups. In terms of hypotheses, it seems that all three political economy hypotheses are relevant. The best classification result is reached (Models 7 and 8 ) if variables relating to the labour surplus link (e.g. generosity of unemployment insurance and level of poverty) are combined with variables representing the insecurity link (e.g. degree of stratification via the social security system) and the bureaucracy link. Model 8 classifies only the UK in the wrong group (in the Scandinavian cluster instead of the Mediterranean cluster), which is not surprising given that the features of the British political economy combine elements of universalism and residualism. Finally, the control variables included in the regressions play a much more marginal role than the indicators representing our theoretically derived hypothesis. The unemployment rate could even be dropped from model 8 without much loss of canonical correlation and classificatory accuracy. The homicide rate, in contrast, does play a certain role - but is less influential than our political economy indicators (such as bureaucracy).

How well do the variables discussed above discriminate between the country clusters? Figure 3 illustrates the results. The graph plots the countries according to the values they take for the two discriminant functions. It is obvious that the two functions discriminate well between the three groups - again, with the exception of the UK, which is put in the midst of the Nordic/Anglo-Saxon cluster. What is more, the graph shows that a good deal of discrimination is already reached with the first function (x-axis), which separates rather clearly the Nordic/Anglo-Saxon cluster from the Mediterranean cluster. The Continental European cluster lies in between these two on function 1. However, the second discriminant function helps us to identify the Continental European cluster 
Table 2 Results of linear discriminant analysis

\begin{tabular}{|c|c|c|c|c|c|c|c|c|}
\hline & \multicolumn{2}{|c|}{1 Pol. econ. } & \multicolumn{2}{|c|}{2 Pol. econ. } & \multicolumn{2}{|c|}{3 Pol. econ. } & \multicolumn{2}{|c|}{4 Pol. econ. } \\
\hline & 1 & 2 & 1 & 2 & 1 & 2 & 1 & 2 \\
\hline \multicolumn{9}{|l|}{ Generosity } \\
\hline unemployment & & & $\begin{array}{l}-0.24 \\
-1.10\end{array}$ & $\begin{array}{r}-0.51 \\
0.00\end{array}$ & & & & \\
\hline Poverty & -1.00 & 0.18 & & & & & & \\
\hline $\begin{array}{l}\text { Social insurance } \\
\text { system }\end{array}$ & -0.78 & -0.92 & -0.68 & -0.77 & & & & \\
\hline $\begin{array}{l}\text { Employment } \\
\text { regulation }\end{array}$ & & & & & & & -0.82 & -0.77 \\
\hline $\begin{array}{l}\text { Active labour market } \\
\text { policies }\end{array}$ & & & & & -0.56 & -0.62 & 0.98 & -0.42 \\
\hline \multicolumn{9}{|l|}{$\begin{array}{l}\text { Labour market } \\
\text { training }\end{array}$} \\
\hline $\begin{array}{l}\text { Professional } \\
\text { bureaucracy }\end{array}$ & & & & & -0.80 & 0.74 & & \\
\hline \multicolumn{9}{|l|}{$\begin{array}{l}\text { Proportional electoral } \\
\text { system }\end{array}$} \\
\hline \multirow{2}{*}{\multicolumn{9}{|c|}{$\begin{array}{l}\text { Two-party system } \\
\text { Individualist culture }\end{array}$}} \\
\hline & & & & & & & & \\
\hline Homicide & 0.33 & -0.06 & 0.40 & -0.17 & -0.54 & -0.48 & 0.51 & -0.43 \\
\hline Unemployment & -0.27 & 0.33 & -0.40 & 0.38 & 0.47 & 1.05 & -0.93 & 0.51 \\
\hline Eigenvalue & 1.27 & 0.32 & 1.81 & 0.50 & 1.66 & 0.11 & 1.59 & 0.04 \\
\hline Canonical correlation & 0.75 & 0.49 & 0.80 & 0.58 & 0.79 & 0.31 & 0.78 & 0.20 \\
\hline Correctly classified & \multirow{2}{*}{\multicolumn{2}{|c|}{$\begin{array}{c}79 \% \\
19\end{array}$}} & \multicolumn{2}{|c|}{$83 \%$} & \multicolumn{2}{|c|}{$72 \%$} & \multicolumn{2}{|c|}{$79 \%$} \\
\hline \multirow[t]{3}{*}{$N$} & & & & & & & & \\
\hline & \multicolumn{2}{|c|}{ 5 PE \& PS } & \multicolumn{2}{|c|}{6 Pol. System } & \multicolumn{2}{|c|}{7 Best fit } & \multicolumn{2}{|c|}{8 Best fit } \\
\hline & 1 & 2 & 1 & 2 & 1 & 2 & 1 & 2 \\
\hline $\begin{array}{l}\text { Generosity } \\
\text { unemployment }\end{array}$ & & & & & -0.60 & -0.60 & -0.62 & -1.26 \\
\hline Income inequality & & & & & -0.96 & 0.36 & & \\
\hline Poverty & & & & & & & -0.49 & 0.92 \\
\hline $\begin{array}{l}\text { Social insurance } \\
\text { system }\end{array}$ & & & & & -0.28 & -0.33 & -0.33 & -0.03 \\
\hline $\begin{array}{l}\text { Employment } \\
\text { regulation }\end{array}$ & & & & & & & 0.43 & 1.75 \\
\hline \multicolumn{9}{|l|}{$\begin{array}{l}\text { Active labour market } \\
\text { policies }\end{array}$} \\
\hline $\begin{array}{l}\text { Labour market } \\
\text { training }\end{array}$ & -0.65 & 0.75 & & & & & & \\
\hline $\begin{array}{l}\text { Professional } \\
\text { bureaucracy }\end{array}$ & & & & & 0.85 & 0.16 & 1.12 & 1.40 \\
\hline $\begin{array}{l}\text { Proportional electoral } \\
\text { system }\end{array}$ & -0.22 & 0.15 & & & & & & \\
\hline Two-party system & & & -0.38 & 0.93 & & & & \\
\hline Individualist culture & & & 0.35 & 0.27 & & & & \\
\hline
\end{tabular}


Table 2 Continued

\begin{tabular}{|c|c|c|c|c|c|c|c|c|}
\hline & \multicolumn{2}{|c|}{5 PE \& PS } & \multicolumn{2}{|c|}{6 Pol. system } & \multicolumn{2}{|c|}{7 Best fit } & \multicolumn{2}{|c|}{8 Best fit. } \\
\hline & 1 & 2 & 1 & 2 & 1 & 2 & 1 & 2 \\
\hline Homicide & -0.82 & -0.10 & 0.40 & 0.29 & 0.24 & -0.07 & 0.30 & 0.34 \\
\hline Unemployment & 1.19 & 0.40 & -0.83 & -0.45 & & & & \\
\hline Eigenvalue & 0.68 & 0.04 & 0.61 & 0.07 & 2.89 & 0.47 & 1.81 & 1.29 \\
\hline Canonical correlation & 0.84 & 0.21 & 0.62 & 0.25 & 0.86 & 0.56 & 0.82 & 0.75 \\
\hline$\overline{\text { Correctly classified }}$ & \multicolumn{2}{|c|}{$53 \%$} & \multicolumn{2}{|c|}{$47 \%$} & \multicolumn{2}{|c|}{$89 \%$} & \multicolumn{2}{|c|}{$94 \%$} \\
\hline$N$ & \multicolumn{2}{|c|}{19} & \multicolumn{2}{|c|}{19} & \multicolumn{2}{|c|}{18} & \multicolumn{2}{|c|}{18} \\
\hline
\end{tabular}

Note: The table displays the standardised canonical coefficients of the variables, the eigenvalue and the canonical correlation of the respective functions as well as the classification results.

\section{Discriminant function scores}

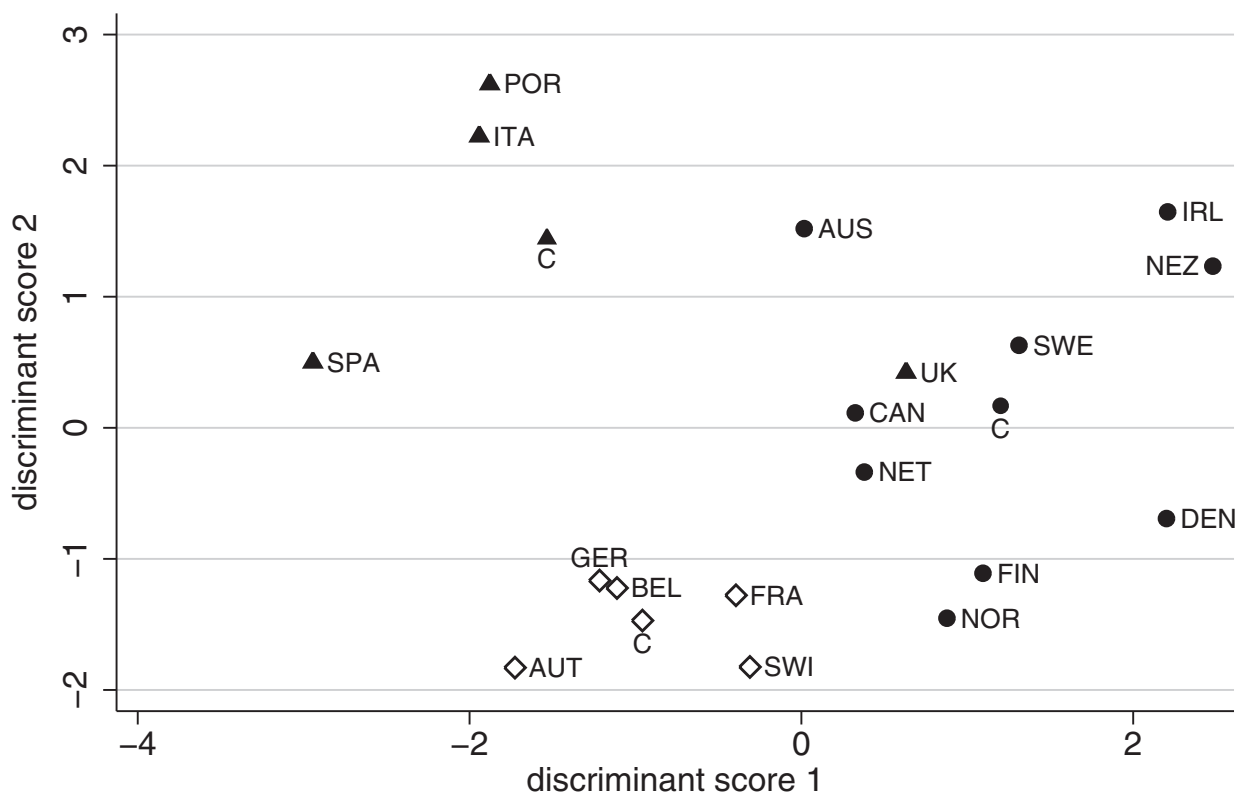

Figure 3. Graphical illustration of the discriminant function scores

Note: Scoreplot based on Model 8 in Table 1. The Mediterranean (plus UK) cluster is symbolised with a triangle, the Continental European cluster with a hollow diamond and the Nordic/Anglo-Saxon cluster with circles. " $\mathrm{C}$ " denotes the centroids of the groups based on the discriminant functions.

as it clearly distinguishes between the Mediterranean and the Continental European countries.

In terms of robustness, it seems that the findings are rather robust to the exclusion of individual countries. The canonical correlations as well as the standardised factors only change slightly. For model 7, for instance, the classification result was slightly worse in two cases (three countries classified wrongly), in six cases slightly better (only one false) 
and when Portugal was excluded, model 7 even classified all remaining 17 countries of the sample in the correct groups. Model 8 was even more stable in terms of classification as there was only one instance where two cases where classified incorrectly (exclusion of Canada) instead of one case. In sum, we therefore think that the results can be interpreted with some confidence even though the number of cases is small.

\section{Conclusion}

This article had a twofold goal. First, it aimed at analysing whether Western industrialised countries form distinct clusters in terms of their law and order policy stance while at the same time overcoming the problematic reduction of law and order on a sole indicator, namely imprisonment rate, which characterises the existing literature. The result of our hierarchical cluster analyses based on a set of six indicators is unambiguous. Yes, there are distinct country clusters - three of them and one clear outlier. The clear outlier is the United States which is characterised by the toughest law and order stance and especially by a particularly high imprisonment rate. The Mediterranean countries (Spain, Portugal and Italy) and the UK follow the US in terms of law and order toughness by some distance, and form a first country group. They are on average more repressive than the remaining nations in all but one category (religious freedom). The Continental European countries represent a second cluster which takes a middle position, whereas the Nordic and the Anglo-Saxon countries (without the UK and the US) are the most liberal in terms of law and order (third cluster). In accordance with some comparative criminological studies (Cavadino and Dignan, 2006; Lacey, 2008), this clustering partially resembles existing typologies from comparative political economy research, such as Esping-Andersen's analysis of different worlds of welfare (Esping-Andersen, 1990, 1999). In contrast, influential classifications according to the features of the political system, such as Lijphart's, seem to be much less related to the country clusters.

In order to check these seeming interrelations more systematically, the second goal of this article was to find patterns in the data that point to associations between the characteristics of the typologies and the classification of countries in terms of law and order policies. Based on empirical evidence from linear discriminant analyses, our findings suggest that the characteristics of the political economy - and especially those related to the labour market and the welfare state - seem to be highly relevant for the country clustering, whereas the institutional architecture of the political system seems to matter much less. Besides, the degree of professionalisation of the bureaucracy, which can also be seen as part of the political economy, also helps to discriminate between the three country clusters. To what extent the architecture of political systems and the characteristics of the political economy are, themselves, intertwined is an open question. Indeed, historically electoral systems affected how capitalist systems developed (Cusack et al., 2007). However, from the results of this analysis, it seems that for law and order policies over the last decade or more, the features of the political economy play an independent role.

These results add to the existing literature in several respects. From a criminological as well as from a social policy perspective, they provide a theoretical and an empirical link between concepts from welfare state research and the classic criminological explanations of penal policies. From a political economy perspective, the article shows that the structure of capitalist systems and welfare states not only affects the directly related economic and 
social policies, but also more distant policies, in this case the policies of law and order. From the patterns observed in the empirical analysis in this article two ways forward seem to be most exciting. On the one hand, future research could dig deeper into the causal mechanisms that exist between law and order policies and the nature of welfare capitalisms using, for instance, qualitative methods and comparisons of nations. This article has stopped at the level of pattern identification using very aggregate measures and focusing solely on cross-country variance. This is a valid starting point for a policy field that has been almost unexplored, but it would be most valuable to add a temporal perspective, identifying causal mechanisms that lead to restrictive or more lenient law and order policies. On the other hand, it would also be most welcome to look into other policy domains in order to see whether the patterns revealed for law and order policies are also present in neighbouring fields.

\section{Acknowledgements}

This research has been supported by a grant of the German Research Foundation (DFG) WE 4775/2-1). The author thanks the members of the "brown bag lunch seminar" at the Social Sciences Department of the TU Kaiserslautern and Stefan Wurster for very helpful comments on an earlier version of this paper.

\section{Notes}

1 Besides, the families-of-nations concept originally developed by Castles (1993) has also been used to make sense of variations in law and order (Norris, 2009). However, as the concept is basically a heuristic linking family resemblances to various attributes and lacking a causal theory which might explain the clustering of nations, we do not include this concept in our inquiry.

2 A laudable exception is Lacey's work (Lacey, 2008) which is much more specific in terms of the supposed relationships. In her account, differences in penal policies result from differences in political systems (electoral system, bureaucracy), the structure of the economy (production regimes, labour markets, skill formation) and the differences in the welfare state. The theoretical argument put forward in this article is related to this work - we refer to the specific points in the discussion of the theoretical framework.

3 Besides, Lacey also takes into account the fact that majoritarian electoral systems significantly reduce the probability of social democratic governments (Iversen and Soskice, 2006) that should, ideologically, favour a less harsh law and order policy stance.

4 The corresponding indicators in the democracy barometer are: Politterr (reversed) (1); Torture (2), and Freerelig (3). The data sources the democracy barometer draws on for these indicators are the Political Terror Scale (Gibney et al., 2015) (1) and the CIRI dataset (Cingranelli et al., 2014) (2 and 3).

5 Admittedly, the imprisonment rate is a very broad measure. We keep this variable nevertheless as it has been widely used in the criminological studies we refer to and because it reflects not only, but also, decisions on resources (see for instance Gottschalk, 2010).

6 Besides technical reasons linked to data availability, there are also sound theoretical grounds which justify the restriction to twenty Western industrialised countries. Our goal is to look at the group of very developed industrialised democracies which have been said to follow a similar policy path of late modern societies (Garland, 2001).

7 We have run robustness tests for the cluster analysis using shorter time periods (dropping one year from the calculation of means). The results are very similar (which may be explained by the 'stickiness' of the indicators used. In fact, the indicators vary much more between countries than over time. For LDA, we have run a jackknife analysis dropping one country at a time (a much tougher test to pass given the strong between-variance of the indicators). Again, the substantive results do not change. 
8 As a rule of thumb, Backhaus et al. (2005: 233) recommends that the number of observations should always be at least two times the number of explanatory variables. We check the robustness of the results by excluding one case at a time and re-estimating the analysis (Williams and Titus, 1988).

9 This is why we also do not systematically report significance tests. However, for those interested in stars, the eigenvalues of function 1 in the final models 7 and 8 were always significant (at the 95 per cent level), and, in case of Model 8, the eigenvalue of second function was significant too (see Table 4).

10 Excluding the US from the sample and re-running the cluster analysis without them does not alter the results.

11 This is true when all independent variables are analysed together (MANOVA) or if one compares the means for each variable independently (ANOVA), except the imprisonment rate.

12 The US is excluded from the following analyses as they represent an outlying single case. Some models are based on only 18 cases because of missing data for Luxemburg.

\section{Supplementary material}

To view supplementary material for this article, please visit https://doi.org/10.1017/ S1474746417000094.

\section{References}

Backhaus, K., Erichson, B., Plinke, W. and Weiber, R. (2005) Multivariate Analysemethoden, Berlin: Springer.

Bauman, Z. (1999) In Search of Politics, Cambridge: Polity Press.

Beck, U. (1986) Risikogesellschaft: Auf dem Weg in eine andere Moderne, Frankfurt: Suhrkamp.

Beck, U. (2011) Weltrisikogesellschaft: auf der Suche nach der verlorenen Sicherheit, Frankfurt: Suhrkamp.

Beck, U., Giddens, A. and Lash, S. (1994) Reflexive Modernization: Politics, Tradition and Aesthetics in the Modern Social Order, Cambridge: Polity Press.

Berk, R. (2010) 'What you can and can't properly do with regression', Journal of Quantitative Criminology, $26,4,481-7$.

Bottoms, A. (1995) 'The philosophy and politics of punishment and sentencing', in C. Clarkson and R. Morgan (eds.), The Politics of Sentencing Reform, Oxford: Oxford University Press.

Bühlmann, M., Merkel, W., Müller, L. and Weßels, B. (2012) 'The democracy barometer: a new instrument to measure the quality of democracy and its potential for comparative research', European Political Science, 11, 4, 519-36.

Castles, F. G. (1993) Families of Nations, Aldershot: Dartmouth.

Cavadino, M. and Dignan, J. (2006) Penal Systems: A Comparative Approach, London: Sage.

Cavadino, M. and Dignan, J. (2014) 'Political economy and penal systems', in S. Body-Gendrot, M. Hough, K. Kerezsi, R. Lévy and S. Snacken (eds.), The Routledge Handbook of European Criminology, London/New York: Routledge.

Chiricos, T. G. and Delone, M. A. (1992) 'Labor surplus and punishment: a review and assessment of theory and evidence', Social Problems, 39, 4, 421-46.

Cingranelli, D. L., Richards, D. L. and Clay, K. C. (2014) 'The CIRI Human Rights Dataset 2014.04.14', http://www.humanrightsdata.com/p/data-documentation.html (accessed 06.03.17).

Cusack, T. R., Iversen, T. and Soskice, D. (2007) 'Economic interests and the origins of electoral systems', American Political Science Review, 101, 3, 373-91.

Downes, D. and Hansen, K. (2006) 'Welfare and punishment in comparative perspective', in S. Armstrong and L. McAra (eds.), Perspectives on Punishment, Oxford: Oxford University Press.

Elazar, D. J. (1966) American Federalism: A View from the States, New York: Crowell.

Esping-Andersen, G. (1990) The Three Worlds of Welfare Capitalism, Princeton, NJ: Princeton University Press. 
Esping-Andersen, G. (1999) Social Foundations of Postindustrial Economies, Oxford: Oxford University Press.

Farrall, S., Burke, N. and Hay, C. (2016) 'Revisiting Margaret Thatcher's law and order agenda: the slowburning fuse of punitiveness', British Politics, 11, 2, 205-31.

Ferrera, M. (1996) 'The "southern model" of welfare in social Europe', Journal of European Social Policy, $6,1,17-37$.

Frost, N. A. (2008) 'The mismeasure of punishment: alternative measures of punitiveness and their (substantial) consequences', Punishment and Society, 10, 3, 277-300.

Garland, D. (1996) 'The limits of the souvereign state', British Journal of Criminology, 36, 4, 445-71.

Garland, D. (2001) The Culture of Control: Crime and Social Order in Contemporary Society, Oxford: Oxford University Press.

Gibney, M., Cornett, R., Wood, R., Haschke, P. and Arnon, D. (2015) 'The political terror scale 1976-2015', http://www.politicalterrorscale.org/ (accessed 06.03.17).

Giddens, A. (1990) The Consequences of Modernity, Stanford, CA: Stanford University Press.

Gottfredson, M. R. and Hindelang, M. J. (1979) 'A study of "the behavior of law"', American Sociological Review, 44, 1, 3-18.

Gottschalk, M. (2010) 'Cell blocks and red ink: mass incaceration, the great recession and penal reform', Daedalus, 139, 3, 62-73.

Greenberg, D. (1983) Crime and Capitalism, Palo Alto: Mayfield.

Hall, P. and Soskice, D. (eds.) (2001) Varieties of Capitalism, Oxford: Oxford University Press.

Huberty, C. J. and Olejnik, S. (2006) Applied MANOVA and Discriminant Analysis, Hoboken: WileyInterscience.

Iversen, T. and Soskice, D. (2006) 'Electoral institutions and the politics of coalitions: why some democracies redistribute more than others', American Political Science Review, 100, 2, 165-81.

Jacobs, D. and Helms, R. (2001) 'Toward a political sociology of punishment: politics and changes in the incarcerated population', Social Science Research, 30, 2, 171-94.

Jankovic, I. (1977) 'Labor market and imprisonment', Crime and Social Justice, 8, 17-31.

Karstedt, S. (2015) 'Cultural peers and penal policies: a configurational approach toward mapping penal landscapes', Punishment and Society, 17, 3, 374-96.

Kury, H. and Ferdinand, T. N. (2011) 'Punitivity: an Introduction', in H. Kury and T. N. Ferdinand (eds.), International Perspectives on Punitivity, Bochum, Unversitätsverlag Dr. Brockmeyer.

Lacey, N. (2008) The Prisoners' Dilemma, Cambridge: Cambridge University Press.

Lacey, N. (2010) 'Système électoral et politiques criminelles: la dynamique de la représentation proportionelle face au système du "winner-takes-all"', Jus Politicum, 4, 1-24.

Lacey, N. (2011) 'The prisoners' dilemma and political systems: the impact of proportional representation on criminal justice in New Zealand', Victoria University of Wellington Law Review, 42, 4, 615-38.

Lacey, N. (2012) 'Punishment in the perspective of comparative political economy', Kriminologisches Journal, 44, 1, 9-31.

Lappi-Seppälä, T. (2014) 'Imprisonment and penal demands', in S. Body-Gendrot, M. Hough, K. Kerezsi, R. Lévy and S. Snacken (eds.), The Routledge Handbook of European Criminology, London/New York: Routledge.

Lappi-Seppälä, T. (2008) 'Trust, welfare, and political culture: explaining differences in national penal policies', Crime and Justice, 37, 1, 313-87.

Lijphart, A. (1999) Patterns of Democracy, New Haven/London: Yale University Press.

Lijphart, A. (2012) Patterns of Democracy, New Haven/London: Yale University Press.

Lowi, T. J. (1972) 'Four systems of policy, politics, and choice', Public Administration Review, 32, 4, 298-310.

Matthews, R. (2005) 'The myth of punitiveness', Theoretical Criminology, 9, 2, 175-201.

Merkel, W., Bochsler, D., Bousbah, K., Bühlmann, M., Giebler, H., Hänni, M. Heyne, L., Müller, L., Ruth, S. and Wessels, W. (2014) Democracy Barometer: Methodology, Version 4, Aarau: Zentrum für Demokratie. 
Mythen, G. (2014) Understanding the Risk Society: Crime, Security and Justice, Basingstoke: Palgrave Macmillan.

Newburn, T. (2006) 'Contrasts in intolerance: cultures of control in the United States and Britain', in T. Newburn and R. Morgan (eds.), The Politics of Crime Control: Essays in Honour of David Downes, Oxford: Oxford University Press.

Newburn, T. (2007) "Tough on crime": penal policy in England and Wales', Crime and Justice, 36, 1, 425-70.

Norris, P. (2009) 'Families of nations: victimisation and attitudes towards criminal justice', International Review of Victimology, 16, 3, 229-55.

Pratt, J. (2007) Penal Populism, London: Routledge.

Pratt, J. (2008) 'Scandinavian exceptionalism in an era of penal excess', British Journal of Criminology, 48, 2, 119-37.

Rusche, G. and Kirchheimer, O. (1968) Punishment and Social Structure, New York: Russell \& Russell.

Savelsberg, J. (2000) 'Kulturen staatlichen Strafens: USA und Deutschland', in J. Gerhards (ed.), Die Vermessung kultureller Unterschiede, Wiesbaden, VS Verlag, https://doi.org/10.1007/ 978-3-322-90239-9_10 (accessed 06.03.17).

Savelsberg, J. J. (1994) 'Knowledge, domination, and criminal punishment', American Journal of Sociology, $99,4,911-43$.

Savelsberg, J. J. (2011) 'Globalization and states of punishment', in D. Nelken (ed.), Comparative Criminal Justice and Globalization, Farnham, Ashgate.

Schmidt, M. G. (1987) 'West Germany: the policy of the middle way', Journal of Public Policy, 7, 2, 135-77.

Schmidt, M. G. (2001) 'Still on the middle way? Germany's political economy at the beginning of the twenty-first century', German Politics, 10, 3, 1-12.

Schneider, M. R. and Paunescu, M. (2012) 'Changing varieties of capitalism and revealed comparative advantages from 1990 to 2005: a test of the Hall and Soskice claims', Socio-Economic Review, 10, 4, 731-53.

Seeleib-Kaiser, M. (2016) 'The end of the conservative German welfare state model', Social Policy and Administration, 50, 2, 219-40.

Singelnstein, T. and Stolle, P. (2012) Die Sicherheitsgesellschaft, Wiesbaden: VS Verlag.

Snacken, S. (2010) 'Resisting punitiveness in Europe?', Theoretical Criminology, 14, 3, $273-92$.

Snacken, S. and Durmontier, E. (2012) Resisting Punitiveness in Europe: Welfare, Human Rights and Democracy, London: Routledge.

Sutton, J. R. (2004) 'The political economy of imprisonment in affluent western democracies, 1960-1990', American Sociological Review, 69, 2, 170-89.

Tonry, M. (ed.) (2007a) Crime and Justice, Volume 36, Crime, Punishment, and Politics in Comparative Perspective, Chicago: University of Chicago Press.

Tonry, M. (2007b) 'Determinants of penal policies', in M. Tonry (ed.), Crime and Justice, Volume 36, Crime, Punishment, and Politics in Comparative Perspective, Chicago: University of Chicago Press.

Wacquant, L. (2009) Punishing the Poor: The Neoliberal Government of Social Insecurity, Durham/London: Duke University Press.

Wagner, A. and Kneip, S. (2015) 'Demokratische gefahr für die demokratie?', in W. Merkel (ed.), Demokratie und Krise, Fachmedien Wiesbaden: Springer, https://doi.org/10.1007/ 978-3-658-05945-3_12 (accessed 06.03.17).

Wenzelburger, G. and Staff, H. (2016) 'German exceptionalism? An empirical analysis of 20 years of law and order legislation', Politics and Policy, 44, 2, 319-50.

Williams, B. K. and Titus, K. (1988) 'Assessment of sampling stability in ecological applications of discriminant analysis', Ecology, 69, 4, 1275-85. 